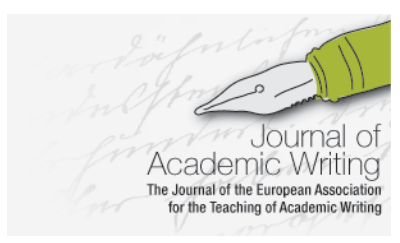

Journal of Academic Writing

Vol. 10 No 1 WINTER 2020, pages 98-112

https://doi.org/10.18552/joaw.v10i1.625

\title{
Embedding Academic Literacies through Growing Student and Staff Communities
}

\author{
Cathy Malone \\ Oxford Brookes University, UK \\ Charlotte Coleman \\ Sheffield Hallam University, UK \\ Elizabeth Freeman \\ Sheffield Hallam University, UK \\ Sue Jamison-Powell \\ Sheffield Hallam University, UK
}

\begin{abstract}
In the UK, HE practical writing support has not kept pace with advances in our understanding of how students learn to write in their disciplines or greater comprehension of the nature of the discourses they are acquiring. Current institutional provision can still be characterised as fragmented, offering generic, deficit focused, skills-based instruction, despite such approaches being theoretically discredited. One alternative means to develop academic literacies in more inclusive and nuanced ways is to embed this work at a disciplinary level; while long recommended, this model is unusual in the UK. This paper reviews approaches to embedding academic literacies work and reports on our attempts to embed writing development work within a social science department through an extended action research project which aimed to increase student mastery of academic literacies within one department. We focused on building opportunities for engagement using Writing Exemplars, Retreats and Writing Circles. Key features of our work are identified that appear transferable and may further facilitate successful interdisciplinary collaborations.
\end{abstract}

\section{Introduction}

Our project takes place in a large social science subject group (approximately $50+$ teaching staff, 500+ students approximately 150/year) in a modern, applied, teaching focused university, (formerly a polytechnic) in the north of England. This is a post-1992 university with a commitment to widening participation and an inclusive agenda to support non-traditional students' access to higher education. Most learning spaces are shared with other subject areas and designed to be multipurpose. Working in this building prompted our first conversations on the importance of learning communities and the challenges of fostering a disciplinary community in anonymous spaces.

This paper provides an account of a collaboration between an educational developer and a small team of faculty academics. In our current context, and common in the UK, support for academic writing is situated centrally, separate from faculty teaching. This paper is an attempt to summarise a long-shared conversation, where we developed together an understanding of what it means to become academically literate at university, the disciplinary "ways of knowing" (Carter, 2007, as cited in Anson et al. 2012, Abstract) embodied in this, and how we explored ways to support development of these skills within the discipline. Underpinning this project were research questions focused on exploring: 
What activities support embedded or integrated academic literacy development appropriate for a humanities department of a post-92 UK university?

Does localised literacy work (exemplars of student writing, writing circles and retreats) impact student development? Specifically, do these interventions impact student confidence and their notions of self- efficacy related to academic writing?

The research questions driving the whole project are too broad in scope to address here. This paper will instead focus on one aspect of the project: our attempts at building a disciplinary writing community. While tracking and researching the impact of discrete strands of our project (exemplars of student writing, writing circles and retreats), the impact of these elements on the staff student community were more than the sum of their parts. We attempted to explore this aspect of our work through capturing our participant reflections. Nevertheless, challenges remained not least because the importance of the staff community was an emergent finding.

Theoretically the case for embedding academic literacies development work at a subject level is over twenty years old (Lea \& Street, 1998). In spite of repeated calls to mainstream this work within a taught curriculum (Lea \& Street, 2006; Jacobs, 2007; Wingate \& Tribble, 2012) academic development in the UK largely remains centrally situated, separate from disciplinary subject teaching. The positioning of this central resource with a specific focus on international students and students with diagnosed disabilities (such as dyslexia) means that while nominally available to all students, academic writing development has a deficit focus. In the UK, in spite of seminal developments in theory and research (Lea \& Street, 1998; Lillis \& Scott, 2007), academic literacies development remains, in practice, a largely invisible aspect of the curriculum, one that only appears discernible in failure. Much of the research cited in this paper is explicitly aligned to an academic literacies frame (Lea \& Street, 1998; Lillis \& Scott, 2007) and some of the key tenets of this approach are central to understanding the current gulf between theory and practice in the way students are supported in their learning at university.

\section{Theoretical Context: Working in an Academic Literacies Frame}

Academic literacies emerged from ethnographic research into the experience of learning to write at university (Lea \& Street, 1998), at a time of significant growth in UK HE. Amid complaints of 'dumbing down', academic literacies research focused on the student experience and crucially provided alternative positive conceptions of non-traditional students (Mann, 2001; Haggis, 2006). Exploring student experiences of learning at university, Lea and Street (1998) revealed some of the identity issues bound up with learning to write in a new discipline. Their work examined "the importance of issues of identity and the institutional relationships of power and authority that surround, and are embedded within, diverse student writing practices across the university" (Lea \& Street, 1998, p.157). This research foregrounded the student experience and went some way to acknowledge and validate some of the anxiety and distress that for many students at university is part of learning to write in a discipline (see also Gourlay, 2009; French, 2018).

As an approach, Academic Literacies acknowledges the complexity of "what it means to become academically literate" (Lea \& Street, 1998, p.158), noting such conceptions are contested. It deliberately views literacy from a cultural and social practices approach drawing on Street's work contrasting autonomous and ideological models of literacy. Lea and Street posited a pluralistic 'literacies', a term which encompasses "a variety of communicative practices, including genres, fields and disciplines"(1998, p. 158). Wingate defined academic literacies as "the ability to communicate competently in an academic community" (2015, p. 7), and Lillis and Scott maintain academic literacies has a recognisable epistemology that of literacy as a social practice, and a transformative ideology (2007). In their 1998 paper, Lea and Street presented a typology of approaches to supporting writing/ literacy development in HE: Study skills, Academic Socialisation and Academic Literacies. Lillis and Scott simplified these to a simple binary which they described as, normative approach (identify and induct) and the 
transformative approach (situate and contest) (2007). However difficult it is to achieve, it is this commitment to transformative purpose of education that has emerged as one of its distinctive features.

To sum up, we seek to position our own work within an academic literacies frame as it acknowledges the complexity of the context we encountered. It affords a voice to the students we work with and seeks to address the challenges they face rather than problematise them, while maintaining a commitment to the transformative purpose of education. The academic literacies framework also begins to explain why the separation of disciplinary specialist (DS) from academic literacies specialist (ALS) is problematic.

\section{Rationale for Embedding: Disciplinary Distinctiveness}

Academic literacies provided a robust case for re-orienting developmental resource from the centre to the faculties. Further research, specifically research demonstrating the presence of disciplinary specific genres (Nesi \& Gardner, 2012), added to this position. In addition to textual distinctions of genres, more recent scholarship has employed richer methodologies that "consider the histories and emergence of situated genres and their complex functions within particular communities" (Anson et al. 2012, para. 4). What emerges are particular "ways of knowing" and situated practices, which account for "the embeddedness of communication ... within disciplines and sub-disciplines" (Anson et al. 2012, Abstract). One implication of acknowledging the specificity of disciplinary discourse is understanding that "writers don't develop abilities generically" (Anson et al., 2012, para. 4); rather "one acquires the genres ... used by some activity field as one interacts with people involved in the activity field and the material objects and signs those people use" (Russell, 1995, p. 56). For these reasons there has been a turn away from centralised generic provision towards siting literacy development work in the faculties.

While there is a forceful critique of current centralised literacy provision (Lea \& Street, 2006; Wingate, 2006; Jacobs, 2007; Wingate \& Tribble, 2012), there is less clarity concerning exactly what embedding literacy work in the faculty entails or how to achieve this transfer. There are, however, a number of models of embedded practice available in the literature, all of which bring together Academic Literacies Specialists (ALS)s and Disciplinary Specialists (DSs).

\section{Models of embedding}

A number of authors have reported in their own attempts to explore how integrating academic literacies development work locally within a disciplinary subject works and what this entails practically for staff and students; Anson et al. (2012), Jacobs (2015), Donohue (2012) and Clarence and McKenna (2017). These authors set out to embed disciplinary writing instruction to produce "faculty-driven (rather than centrally-mandated) context-specific curricular change leading to improved student writing" (Anson et al. 2012, para. 22). While all shared an aim to make the workings of disciplinary discourses explicit, they also shared a commitment to moving along a normative to transformative trajectory (Lillis \& Scott, 2007).

Some key features of their work are summarised in Table 1 below. 
Table 1

A Comparison of Interventions Embedding Literacy Development Work

\begin{tabular}{|c|c|c|c|}
\hline Title & $\begin{array}{l}\text { Who's } \\
\text { involved }\end{array}$ & Activities & Focus and Key features \\
\hline $\begin{array}{l}\text { Anson et al. } \\
\text { (2012) } \\
\text { Staff } \\
\text { Development for } \\
\text { Curriculum } \\
\text { Change }\end{array}$ & $\begin{array}{l}\text { ALs } \\
\text { /Developers } \\
\text { and DS staff } \\
\text { teams }\end{array}$ & $\begin{array}{l}\text { - Facilitating group } \\
\text { discussions in } \\
\text { workshops, with a } \\
\text { focus on curricula and } \\
\text { assessment criteria } \\
\text { - Creation of "situated } \\
\text { approaches to the } \\
\text { assessment of writing } \\
\text { and speaking" (2012, } \\
\text { p. 1). }\end{array}$ & $\begin{array}{l}\text { 1/ those who teach in the } \\
\text { disciplines should shape } \\
\text { the writing instruction } \\
\text { and assessment } \\
2 / \text { it is essential for local } \\
\text { faculty groups to } \\
\text { examine and revise } \\
\text { assumptions about what } \\
\text { writing and writing } \\
\text { instruction look like }\end{array}$ \\
\hline $\begin{array}{l}\text { Jacobs; } \\
\text { Collaborative } \\
\text { Pedagogy } \\
\text { (2015) } \\
\text { A cross } \\
\text { institutional } \\
\text { literacy } \\
\text { development } \\
\text { program }\end{array}$ & $\begin{array}{l}\text { Pairs of ALSs } \\
\text { and DSs }\end{array}$ & $\begin{array}{l}\text { - Analysis of disciplinary } \\
\text { discourse } \\
\text { - Development of } \\
\text { teaching materials } \\
\text { - Team teaching, } \\
\text { - Co-researching the } \\
\text { intervention }\end{array}$ & $\begin{array}{l}\text { "the explicit teaching of } \\
\text { disciplinary literacy } \\
\text { practices through } \\
\text { unlocking the tacit } \\
\text { knowledge that the } \\
\text { disciplinary lecturers had } \\
\text { of these literacy practices" } \\
(2015, \text { p. 139). }\end{array}$ \\
\hline $\begin{array}{l}\text { Donohue (2012); } \\
\text { Case study of } \\
\text { embedding with } \\
\text { SFL as an } \\
\text { analytical tool }\end{array}$ & ALS and DS & $\begin{array}{l}\text { - Applying Systemic } \\
\text { Functional Linguistics } \\
\text { to analyse course } \\
\text { materials and student } \\
\text { writing } \\
\text { - Researching the } \\
\text { course as participant } \\
\text { observer } \\
\text { - Team teaching } \\
\text { - Design assessment } \\
\text { materials }\end{array}$ & $\begin{array}{l}\text { "Students are not just } \\
\text { using language, they are } \\
\text { making meanings in } \\
\text { context. That their writing } \\
\text { may display a need for } \\
\text { development is not simply } \\
\text { a language development } \\
\text { need, it is a meaning } \\
\text { development need" (2012 } \\
\text { p. 15). }\end{array}$ \\
\hline $\begin{array}{l}\text { Clarence and } \\
\text { McKenna } \\
\text { (2017); } \\
\text { Developing } \\
\text { Academic } \\
\text { Literacies } \\
\text { through } \\
\text { Disciplinary } \\
\text { Knowledge }\end{array}$ & $\begin{array}{l}\text { Pairs of DSs } \\
\text { and ALSs }\end{array}$ & $\begin{array}{l}\text { Analysis of knowledge } \\
\text { structures, (using Maton's } \\
\text { Legitimation Code Theory } \\
\text { 2014), to uncover 'the } \\
\text { underpinning logics and } \\
\text { drivers of the disciplines' } \\
\text { (2017, p. 40). }\end{array}$ & $\begin{array}{l}\text { An understanding of how } \\
\text { disciplinary knowledge is } \\
\text { structured is central } \\
\text { because "knowledge itself } \\
\text { acts to shape and } \\
\text { determine what counts as } \\
\text { context, and how one } \\
\text { needs to read, write, think } \\
\text { and act within such } \\
\text { contexts". (2017, p. 39). }\end{array}$ \\
\hline
\end{tabular}

Different models of embedding emphasise distinct aspects of this relationship between ALSs and DSs. Anson et al. (2012) focus on the time required for meaningful staff engagement that is a pre-requisite of change, while Jacobs (2015) stresses the need to create neutral 
interdisciplinary spaces to support staff to collaborate across disciplinary lines. Both look at institutional models of embedding literacies development work. The last two models focus on a smaller scale: Donohue (2012) applies SFL as an analytical framework, while Clarence and McKenna (2017) use Maton's LCT to examine disciplinary knowledge structures. We kept these diverse approaches in mind in exploring practices suitable for our own context.

\section{Current Project}

\section{Background}

HE faculty staff and students in the UK are widely acknowledged as time poor. During this project academics across the sector have engaged in sustained industrial action concerning deteriorating pay and conditions (Grady, 2019; Pells, 2020). Responsibility for academic literacy development is thus only one of a number of competing agendas that disciplinary teaching staff now juggle. For students, paid work is now a normal part of the university experience and as it encroaches on study time, students display an acute sensitivity to the positioning of literacy in the curriculum. Consequently, siting it outside their subject curriculum marks it as 'nonessential' university provision, reinforcing the deficit framing of literacy in the HE curriculum.

In this context we wanted to work within an academic literacies frame with its clear orientation to inclusivity (Wingate, 2015). Our goal was to create learning experiences that were available to all students as an ordinary part of their course rather than providing development accessible as a result of an individual identifying personal shortcomings. Where possible, we agreed that "writing development should be embedded in disciplinary teaching, led by disciplinary specialists" (Mitchell, 2010, p. 136). Our desire to embed this work in the taught curriculum was confirmed by an understanding of the integrity of thinking and writing. We also agreed on the need for disciplinary staff involvement, recognising their expertise in disciplinary literacy.

A key challenge for us was one of scale. Both Jacobs (2015) and Anson et al. (2012) worked at a departmental level; however, Anson et al. (2012, para. 7) focused on creating a "Writing Enriched Curriculum", while Jacobs (2015) coordinated a team of ALSs. In our context there was one ALS to over fifty DSs. This had defining practical consequences for our project.

The project focused on delivering an inclusive, sustainable model of disciplinary writing development and our case study tracks the process of moving development activities from extra-curricular to more fully embedded and locally owned. As well as attempting to research the impact of each of these initiatives (exemplars, writing circles and retreats) through simple pre- and post-evaluations, we were concerned with tracking and exploring the nature of community building which was central to the long-term sustainability of the project. This involved a different research approach, which drew on capturing our reflections as participants.

\section{Approach to research}

Our approach to this research combined elements of collaborative action research (Burns, 1999) and exploratory practice (EP) (Allwright, 2005). An underlying assumption of action research is that it sets out to improve conditions and practices for all participants through the process of engaging in the project. The messy complexity of action research seemed appropriate to our live teaching context and acknowledged the scale of the system change we hoped to effect. This practice driven approach to research is underpinned by an understanding of organisational change aligned with Cattel's description of complex systems (2013).

The strengths of action research, in the way it identifies problems and seeks to identify and implement practical solutions, aligned with our focus on the student experience. The cycle of action research and reflection (Altrichter et al., 2007, p. 8) allowed us to foreground practice and to work systematically in data gathering, meeting periodically to subject our analyses and understanding to critical scrutiny. At the same time, EP utilises "normal pedagogic practices as investigative tools" (Allwright, 2003, p. 127) co-opting roles of researcher, teacher and learner in the classroom to develop a commitment to answer shared questions in a way that is sustainable, and builds on participant strengths. 
These approaches also seemed a good fit for a project requiring collaboration across disciplinary and institutional boundaries and reflected the need for us to work appreciatively, acknowledging different perspectives and specialisms (Cooperrider \& Srivastava,1987). This is illustrated in the composition of our team and how we worked together. We consisted of a centrally based academic developer, and three academic colleagues from a subject group of Psychology, one with responsibility for learning development within the subject group and another with responsibility for the three-year tutorial provision. All three faculty colleagues were research active lecturers and tutors. The different responsibilities within our group contributed to a valuable dynamic as critical friends. In our small team responsibilities were divided: one colleague led on the research and evaluation; another colleague led on the pilot of the writing circles and developing associated materials; another manged the writing retreats and supported the embedding of activities and materials into the tutorial strand of the course. We all worked on developing the exemplars and working with the larger staff group. This work spread through the whole project. The extent of this work to keep the project current was significant and also something that is extremely challenging to manage from outside a subject group.

\section{Intervention 2017-2020: building a disciplinary writing community}

The study was implemented over two years following a successful initial pilot. During the pilot we established three distinct interventions and in the following two years we focused on embedding these activities in the fabric of the curriculum and practices of the wider subject group.

1. Exemplars: Samples of Effective (high scoring) student writing with staff audio commentary

2. Writing Retreats: shared space for writing to encourage the production of drafts

3. Writing Circles: Group reading of drafts to support editing and redrafting

The rationale behind the activities was largely driven by an academic socialisation model (as identified by Lea \& Street, 1998) with a view to strengthening the student disciplinary writing community, and a necessary first step to create a space to discuss writing. We focused on recognising the features of high quality disciplinary academic writing (Sadler, 2010; Scoles et al., 2013; Mitchell \& Riddle, 2000), supporting development of independent control of the writing process, and developing practices of expert writers. We aimed to create social opportunities to engage in writing using practices that we valued as writers. This was significant in acknowledging the identity and affective issues at stake in acquiring a different voice (Clark \& Ivanic, 1997; Gourlay, 2009; French, 2018). We aimed to create opportunities to discuss writing in depth and, in this way, we aimed to create transformative experiences.

To look at each of these strands in turn, Writing Circles have moved from an extracurricular pilot delivered by ALS to become embedded in the curriculum and delivered in student group tutorials in year 1 and 2 of the undergraduate course. See Appendix for format and structure of Writing Circles. They continue to be offered in extracurricular fashion for third year students and with postgraduate students. This last year of the project we have begun training and supporting peer leaders to manage their own writing circles. We worked to explore the role students could have in supporting the development of a writing community and consciously created opportunities for them to lead.

Retreats remained an extra-curricular offer, in that student attendance was optional; however, they are rooted in the faculty, led by subject staff, and aligned to the departmental curriculum. They are relatively freely structured, organised around student writing schedule and focusing on the third-year timetable for their dissertation. As the project grew, they have been opened to all students and the number of retreats has increased so they are offered in both autumn and spring, and students are taking a role advertising and promoting these activities.

The exemplars of high scoring writing were a collaboratively created resource. DSs chose examples of effective students writing and were recorded explaining what they valued about the text, relating their comments to specific examples. This strand of the project provided a means to collaboratively engage in examining student writing and explore the features that the 
staff group valued, working appreciatively with the existent (meta) discourse and building on this. Staff naturally described texts in terms of what the writer is doing which provided a functional move analysis (after Swales, 1990). The language analysis applied here was minimally intrusive, designed to add to the existing discourse and develop consistency across staff perspectives.

\section{Methods}

Working within an action research frame meant working together as a team of critical friends throughout the course of the project. The nature of the interventions required a range of evaluation measures focusing mainly on the student experience, summarised in Table 2 below.

Table 2

Evaluation Methods

\begin{tabular}{|c|c|c|}
\hline Intervention & \multicolumn{2}{|l|}{ Evaluation Measures } \\
\hline \multirow[t]{2}{*}{ Cross Intervention } & \multicolumn{2}{|l|}{ Student Focus Groups } \\
\hline & \multicolumn{2}{|c|}{$\begin{array}{l}\text { Pre -post measures of self-efficacy and confidence in } \\
\text { academic writing (measured via questionnaire). These } \\
\text { measures were adapted from Huerta et al. (2017) }\end{array}$} \\
\hline \multirow[t]{2}{*}{ Writing Circle } & Co-curricular & Embedded \\
\hline & Student Focus Groups & $\begin{array}{l}\text { Team Teaching } \\
\text { Observation Notes }\end{array}$ \\
\hline Retreat & \multicolumn{2}{|l|}{ Attendance data } \\
\hline Exemplars (available online) & \multicolumn{2}{|l|}{ Tracking usage data } \\
\hline
\end{tabular}

We gathered data regularly in order to continually evaluate elements of the projects and inform ways forward. We tracked engagement in each of the initiatives through capturing usage and attendance data as well as capturing richer data (observation notes of team teaching and staff and student focus groups and interviews) that approached the work holistically. Recordings of focus groups were transcribed and student responses coded using pseudonyms to maintain anonymity. They were then thematically analysed (after Braun \& Clarke, 2006) to identify key themes.

\section{Results}

This section includes a selection of the large dataset that was at the heart of this project. Overall, there were many indications that the interventions were received positively, due to increasing engagement in each of the strands year on year and the responses and reflections of the students and staff. Cohort sizes varied, the maximum for any one initiative was 120 students. While engagement with pilot co-curricular initiatives remained low (30\% $\leq, \mathrm{n} 45)$, there was always a significant uptick in engagement from third year dissertation students. Response rates for the end of year formal evaluation (an unrewarded extra-curricular activity) remained somewhat problematic throughout, ranging from 10\%-20\%. All focus group participants, were final year students, our most engaged group.

\section{Pre- and post- self-report measures}

For each year of three years of the project we gathered whole year group self-report measures of confidence in writing and self-efficacy at the beginning and end of the year (October to May) for those cohorts engaged in the interventions. So, working from the third year student group backwards, in year one of the project we evaluated the third years only and then cumulatively added second year students in year two as initiatives were embedded, and first year students in year 3. Table 3 shows the results from the second year of the project and shows the mean 
ratings at time 1 (beginning of October 2018) and time 2 (beginning of April 2019). These results are indicative of those gathered throughout the project, and are presented as a representative sample. They reveal positive results. The data suggested that students felt that they were more able to manage the writing process, found it easier to plan their text over time, and interestingly felt that despite sharing their work with others, they were able to maintain ownership of the writing process. During the intervening period this cohort of students had access to exemplars online, had experienced writing circles in tutorials, and had attended writing retreats.

\section{Table 3}

Pre- and Post-Measures of Confidence in Writing and Self-Efficacy

\begin{tabular}{|l|l|l|}
\hline Item & Time 1 & Time 2 \\
\hline How confident do you feel of your ability to... & & \\
\hline manage the research process & 2.67 & $3.40^{\star}$ \\
\hline manage writing a text over a few months & 3.53 & $4.20^{\star}$ \\
\hline produce a lengthy piece of academic writing & 3.07 & 3.56 \\
\hline express your ideas to an academic audience & 2.67 & 2.67 \\
\hline edit and improve your writing & 3.53 & 3.73 \\
\hline proofread and polish your work & 3.33 & $3.87^{\star}$ \\
\hline work with your peers on your writing & 3.67 & 3.87 \\
\hline maintain ownership of the final piece of work & 3.53 & $4.07^{\star}$ \\
\hline Overall Confidence in Writing & 3.25 & $3.67^{\star}$ \\
\hline Self-Efficacy & 3.09 & 3.17 \\
\hline
\end{tabular}

Note: *Significant difference at $\mathrm{p}<.05, \mathrm{~N}=15$

\section{Student focus group responses}

Student focus groups were carried out at the end of each of the three years the project ran (34 focus groups each year, 8 -12 students in each round a total of 36 students interviewed in total). Student comments gathered from focus groups generally revealed a very positive response to the initiatives. A thematic analysis of student responses was conducted to identify key or common themes, these are included below

The students mentioned in particular valuing the social support available to them through working closely with peers on retreats and attending writing circles and how this helped them manage the challenges of the third year. Students indicated that they found real value in engaging in the practice of editing collaboratively and reading peer drafts.

I didn't really expect it to be a few people just sitting around and reading each other's work, I thought it would be you teaching us how to structure. But I think this is more helpful, actually bringing your work and talking with people about reading other people's, because I learnt a lot from reading other people's work instead of just listening to how we should do a structure.

They valued reading one another's work and subsequent close work around text. Some found the experience quite revelatory and it prompted an awareness of the reader's experience and a shift towards more reader focused writing.

I got loads of things that I still do now in my writing from reading other people's.

The students shared concerns over the range of different text types they had to demonstrate mastery of, in addition to more traditional discursive academic essays. The specificity of the textual features that were discussed reflected the highly situated literacies integral to disciplinary academic writing.

There was significant anxiety concerning what it was to be academic and how that was marked in the texts they wrote. 
It was hard knowing how academic you should be ... It makes you think, am I doing it right? ... I never knew if it was academic or not.

It is worth noting that what students termed 'academic' was in reality writing that closely aligned with disciplinary expectations specific to this subject group. The writing circles and retreats proved to be places where these concerns could be addressed at a local level, with some degree of disciplinary specificity. These environments added to the subject level discussions and resources already in place, and provided a space for students to repeatedly revisit these concerns.

A number of students mentioned growing in confidence in academic writing, which applied to their practices as writers (control of techniques) and a related improved sense of control over their ideas.

I feel more confident in an assignment. I will read over all the context and then be like, right, this is what l'm going to put in this paragraph, do my claim, evidence, implication, structure the paragraph and then move on to the next paragraph and then be like, how does this link to that?

The closeness of the relationship between the mechanics of writing and the text as a vehicle for articulating their ideas was new for many students.

but I didn't realise how in depth you would go, but I'm glad you did. Because I expected them to be like yeah, just sort your punctuation out, that's spelled wrong, but you actually went into the subject, and I think that made me realise what I was talking about sometimes ... then l'd sort of see the end of the, where I was at and going with the argument, so yeah.

From the focus groups and notes on the writing circles themselves, students demonstrated concerns about the boundaries of their disciplinary community that they sought entry to. The extent to which a student could be 'present' within their own writing was a frequent topic of conversation in writing circles. What became evident was that focus on form (i.e., use of first person, order of ideas in text, marking stance, interpreting evidence) led to much deeper questions concerning intention, identity, voice and permission and student presence in the discourse.

Similarly, student comments revealed concerns with issues of identity, a focus on the self in relation to the community and issues of power in consistently questioning, not just how is this done in this field, but whether they were entitled to contribute.

I used to think everything needs a reference ... If nobody said it, I can't give it. So, I feel I'm more confident in doing that now. There's ways in which you can put, not your own input but your summary of what you understood without a reference.

A positive indicator of the impact of these interventions (use of exemplars, retreats, and circles) is evident in the richer more nuanced accounts of writing from the students We would claim that these activities required students pay close attention to text (process and product) which developed a sense of control and ownership of their own work. This control and ownership, we would suggest has the potential to be personally empowering and educationally transformative (Lillis \& Scott, 2007).

\section{Discussion}

Reflecting on the experience of delivering these interventions and on the results of student focus groups, we as participants reflecting on the process, identified some key features to our interventions which appeared to have transformative impact on students. 
- Establishing a socially supportive group context

- Acknowledgement of complexity of academic writing and degree of challenge and risk

- Timing aligned to student deadlines

- Creating multiple opportunities for practice

- Supporting close work around text

- Modelling simple functional analysis of text thereby providing a simple metalanguage

- Scaffolding to allow for tutor withdrawal and increasing student leadership

These features were identified through reflecting on our shared practice as staff members over three years of the project through numerous collaborative discussions. Identifying these elements allowed us to create a staged approach to embedding, building each aspect incrementally through the whole course of the project. The nature of these interventions evolved over time, shaped in part by the exploratory nature of action research and also the challenges of influencing a large subject group.

Examining these results in the light of the literature on embedding, it is evident our work intersects with other models in specific ways. Our research findings (with a limited response rate and based largely on self-report data) are a long way from offering definitive proof that these interventions worked in terms of consistently improving the quality of student writing. A conundrum we faced in evaluating the project which is worth noting here, was the tension between evaluating practices and approaches that we were simultaneously attempting to embed and normalise within the subject group. As we normalised practices, they became less noteworthy and visible to the participants themselves. This we felt had an impact on the readiness of participants to engage in evaluating elements of the project and this contributed to the relatively poor response rate. Our research however is in line with much Academic literacies research that demonstrates that students benefit from local writing development interventions. What this project does offer are some interesting, indicative findings based on our experience of building a faculty based academic writing community.

Research in this area (Jacobs, 2015; Donohue, 2012; Clarence \& McKenna, 2017) focuses largely on DS ALS dyads with significant attention paid to linguistic analytic approaches and relatively little attention paid to dissemination of effective practices across larger staff groups. Similar to the four models described earlier, our work involves a cross institutional partnership of ALS and DS and our work demonstrates the value language analysis can contribute to such a partnership. Not least the fact that an outsider perspective requires DS and students to revisit assumptions about 'academic writing'. Our work on exemplars has parallels with Anson et al. (2012) in that it required of staff a more precise articulation of disciplinary expectations. There are similarities with the work of Jacobs (2015) and Anson et al. (2012) and our project, in scope and the means by which we collaborated as a team (through team teaching, and coresearching). Our approach to embedding was distinctive in that it prioritised collaborative enquiry over specific models of textual analysis (compared to Donohue, 2012 and Clarence \& McKenna, 2017). A key tenet of this approach is the firm belief that incremental changes matter, and the success of such an approach is dependent on a thoroughly pragmatic orientation that values the skills and knowledge of all participants. This is not to diminish the importance of language analysis however; our purpose here was not to impose a prescriptive approach to text but to extend staff student dialogue and provide just sufficient tools for students to unpack drafts. The incremental changes evident in this project were practice rather than theory driven and evident in how each strand of the project grew year on year, involving cumulatively more DSs and students each year. In this way a local disciplinary writing community was strengthened.

An action research perspective allowed us to foreground the student and staff experience of being involved in these initiatives. It was the positive student experience that drove the continuation and development of each strand of the project and allowed them to develop year on year, using DS understanding of their faculty and curricula to position the embedding work and grow the projects at a local level. 
Straddling the space between centralised and embedded delivery is an awkward space for any project to occupy, as it communicates departmental ambivalence. It did however in this instance allow for staff and student engagement in the project and allowed us to nurture and engage a small community of interested staff and students which grew over time. This didn't provide for quick wins, rather this approach of scholarly informed interventions allowed for longer term growth more wholly owned by the faculty.

Our success in growing a departmental writing community appeared to be the synthesis of a number of factors. The first of these was that Academic literacies provided a robust theoretical frame and basis for scholarly collaboration. The second was an action research approach which allowed us to foreground the student experience of learning and value confidence building and affective relational aspects of learning. It also allowed us to take seriously the realities of cross disciplinary working and created an interdisciplinary forum and frame for our ongoing discussions. Finally, the commitment to long term project was also central to its success. Combining these elements was crucial in establishing and sustaining buy in and supporting the growth of the project.

These results reaffirmed the need to work with the broader group of subject lecturers over the longer term to continue to create buy in, foster local ownership and expand our shared conception of writing community. This is a project which we are still engaged with. In our massified university context we would suggest this is a largely unexplored area. The challenge looking forward is how to further extend the reach of these practices to the larger staff group in the discipline.

\section{Conclusion}

We can conclude that use of Exemplars, Writing Circles, and Retreats effectively created accessible forums supporting detailed discussions among undergraduate student writers. An unlooked for finding was that in focusing our efforts on nurturing a student community through focusing on socially supportive writing interventions, what we inadvertently developed was a space for interdisciplinary staff collaboration, and staff student co-working. We established a productive cross disciplinary working relationship and have seen positive impact of our work with students; however, we are still at the beginning of the journey influencing the larger staff group. The fact that it takes time to affect real change has been mentioned by many working in this field (Anson et al., 2012; Jacobs, 2015).

Our working partnerships demonstrate academics "inching into each other's disciplinary spaces as a result of sharing the space" (Ingle \& Yakovchuk, 2015, p. 151) as ALSs discussed and probed content and meaning and DSs discussed form and accuracy. One benefit of this project was that action research facilitated a space for discussion between normative and transformative learning, which required both ourselves and our students to transgress disciplinary boundaries and test the limits of insider/ outsiderness (Rai \& Lillis, 2011). We felt the complex messiness of action research suited the context but was at odds with current academic development project management tools, as it maps poorly onto agendas set by Key Performance Indicators. This disconnect may suggest a need to review how academic development initiatives are measured and evaluated.

In conclusion, we would suggest principles of academic literacies (Lillis \& Scott, 2007), and appreciative inquiry (Cooperrider \& Srivastava, 1987) that we applied reflexively to our own work can be usefully adapted to a change project of this size in a large subject group. While this project aimed ultimately to be transformative and critical, the means to achieve this were through dialogue, consultation and valuing perspectives and insights. This was necessary to engage time poor staff and students, explore shared conceptions of literacy, create curricular spaces for literacy development and collaboratively model and develop practices over the longer term. The results of this project have wider implications for the design and management of academic literacies development projects. 


\section{References}

Aitchison, C. (2003). Thesis writing circles. Hong Kong Journal of Applied Linguistics, 8(2), 97115.

Allwright, D. (2003). Exploratory Practice: Rethinking practitioner research in language teaching. Language Teaching Research, 7(2), 113-141.

https://doi.org/10.1191/1362168803/r1180a

Allwright, D. (2005). Developing principles for practitioner research: The case of exploratory practice, The Modern Language Journal, 89(3), 353-366. https://doi.org/10.1111/i.1540-4781.2005.00310.x

Altrichter, H., Posch, P., \& Somekh, B. (1996). Teachers Investigate their Work. Routledge.

Anson, C., Dannels, D. P., Flash, P., \& Housley-Gaffney, A. L. (2012). The futility of using generic assessment tools across diverse instructional contexts. The Journal of Writing Assessment, 5(1). http://journalofwritingassessment.org/article.php?article=57

Braun, V., \& Clarke, V. (2006). Using thematic analysis in psychology. Qualitative Research in Psychology, 3(2), 77-101.

Burns, A., (1999). Collaborative Action Research for English Language Teachers. Cambridge University Press.

Caukill, E. (2017, June 17). Learning to lead: how academic writing circles prepare doctoral students to extend their peers' academic writing skills [Conference presentation]. 9 ${ }^{\text {th }}$ Conference of the European Association for Teaching Academic Writing (EATAW), London.

Chihota, M. (2008). "The Games People Play": Taking on Postgraduate Identities in the Context of Writer Circles. Journal of Applied Linguistics, 4(1). https://doi.org/10.1558/japl.v4i1.131

Clarence, S., \& McKenna, S. (2017). Developing academic literacies through understanding the nature of disciplinary knowledge. London Review of Education, 15(1), 21-37. https://doi.org/10.18546/LRE.15.1.04

Clark, R., \& Ivanic, R. (1997). The Politics of Writing. Routledge.

Cooperrider, D., \& Srivastava, S. (1987). Appreciative inquiry in organizational life. In R. Woodman and W. Pasmore (Eds.), Research in organizational change and development (pp. 129-169). Emerald.

Donohue, J. (2012). Using systemic functional linguistics in academic writing development: an example from film studies. Journal of English for Academic Purposes, 11(1), 4-16. https://doi.org/10.1016/].jeap.2011.11.003

French, A. (2018). Academic Writing: Anxiety, Confusion and the Affective Domain: Why Should Subject Lecturers Acknowledge the Social and Emotional Aspects of Writing Development Processes? Journal of Academic Writing, 8(2). 202-211. https://doi.org/10.18552/joaw.v8i2.487

Gourlay, L. (2009). Threshold practices: becoming a student through academic literacies, London. Review of Education, 7(2), 181-192.

https://doi.org/10.1080/14748460903003626 
Grady, J. (2019, November 7). University staff don't want to strike for fair pensions and pay, but we're being forced to. The Guardian.

https://www.theguardian.com/education/2019/nov/07/university-staff-dont-want-to-

strike-for-fair-pensions-and-pay-but-were-being-forced-to

Haggis, T. (2006). Pedagogies for diversity: retaining critical challenge amidst fears of 'dumbing down'. Studies in Higher Education, 31(5), 521-535.

https://doi.org/10.1080/03075070600922709

Huerta, M., Goodson, P., Beigi, M., \& Chlup, D. (2017). Graduate students as academic writers: writing anxiety, self-efficacy and emotional intelligence. Higher Education Research and Development, 36(4), 716-729.

Pells, R. (2016, May). University and college staff plan nationwide strike action over pay dispute. The Independent. https://www.independent.co.uk/news/education/educationnews/university-and-college-staff-plan-nationwide-strike-action-over-pay-dispute$\underline{\text { a7016901.html }}$

Ingle, J., \& Yakovchuk, N. (2015). Writing Development, Co-Teaching and Academic Literacies: Exploring the Connections. In T. Lillis, K. Harrington, M. Lea \& S. Mitchell (Eds.), Working With Academic Literacies: Case Studies Towards Transformative Practice (pp. 143-154). WAC Clearinghouse.

https://wac.colostate.edu/books/lillis/chapter10.pdf

Jacobs, C. (2007). Towards a critical understanding of the teaching of discipline specific academic literacies: Making the tacit explicit. Journal of Education, 41, 59-81.

Jacobs, C. (2015). Opening up the curriculum: moving from the normative to transformative in teachers understanding of disciplinary literacy practices. In T. Lillis, K. Harrington, M. Lea \& S. Mitchell (Eds.), Working With Academic Literacies: Case Studies Towards Transformative Practice (pp. 131-141). WAC Clearinghouse. https://wac.colostate.edu/docs/books/lillis/chapter9.pdf

Lea, M., \& Street, B. (1998). Student Writing in Higher Education; an academic literacies approach. Studies in Higher Education, 23, 157-172. https://doi.org/10.1080/03075079812331380364

Lea, M., \& Street, B. (2006). The "academic literacies" model: Theory and applications. Theory into Practice, 45(4), 368-377. https://doi.org/10.1207/s15430421tip4504 11

Lillis, T., \& Scott, M. (2007). Defining academic literacies research: issues of epistemology, ideology and strategy, Journal of Applied Linguistics, 4(1), 5-32.

Mann, S. J. (2001). Alternative perspectives on the student experience: alienation and engagement. Studies in Higher Education, 26(1), 7-19. https://doi.org/10.1080/03075070020030689

Maton, K. (2014). Knowledge and Knowers: Towards a realist sociology of education. Routledge.

Mitchell, S., \& Riddle, M. (2000). Improving the quality of argument in higher education (Final Report). Middlesex University.

Mitchell, S. (2010). Now you don't see it; now you do: Writing made visible in the university. Arts and Humanities in Higher Education, 9(2), 133-148. https://doi.org/10.1177/1474022210361452

Nesi, H., \& Gardener S. (2012). Genres Across the Disciplines: Student Writing in Higher Education. Cambridge University Press. 
Pasternak, D. L., Longwell-Grice, H., Shea, K. A., \& Hanson, L. K. (2009). Alien environments or supportive writing communities? Pursuing writing groups in academe. Arts and Humanities in Higher Education, 8(3), 355-367. https://doi.org/10.1177/1474022209339958

Rai, L., \& Lillis, T. (2011). A case study of a research-based collaboration around writing in social work. Across the Disciplines, 8(3), 1-9. http://wac.colostate.edu/atd/clil/lillis-rai.cfm

Roberts, S. K., Blanch, N., \& Gurjar, N. (2017). Exploring Writing Circles as Innovative, Collaborative Writing Structures with Teacher Candidates. Reading Horizons, 56(2). https://scholarworks.wmich.edu/reading horizons/vol56/iss2/2/

Russell, D. (1995). Activity Theory and Its Implications for Writing Instruction. In J. Petraglia (Ed), Reconceiving Writing, Rethinking Writing Instruction (pp. 51-78). Erlbaum.

Sadler, D. R. (2010). Beyond Feedback: Developing student capability in complex appraisal. Assessment and Evaluation in Higher Education, 35, 535-550. https://doi.org/10.1080/02602930903541015

Scoles, J., Huxham, M., \& McArthur, J. (2013). No longer exempt from good practice: using exemplars to close the feedback gap for exams, Assessment and Evaluation in Higher Education, 38(6), 631-645, https://doi.org/10.1080/02602938.2012.674485

Street, B. (2000). Introduction. In B. Street (Ed.), Literacy and Development: ethnographic perspectives (pp. 7-8). Routledge.

Swales J. M. (1990). Genre analysis: English in academic and research settings. Cambridge University Press.

Wingate, U. (2006). Doing away with 'study skills'. Teaching in Higher Education, 11(4), 457469. https://doi.org/10.1080/13562510600874268

Wingate, U., \& Tribble, C. (2013). From text to corpus - A genre-based approach to academic literacy instruction. System, 34(2), 307-321. https://doi.org/10.1016/i.system.2013.03.001

Wingate, U. (2015). Academic Literacy and Student Diversity: The Case of Inclusive Practice. Multilingual Matters. 


\section{Appendix: Writing Circles}

What is discussed in the writing circle stays there.

Participation is always polite.

In successful writing circles everyone contributes and no one dominates

Critical comments need to be both positive and helpful.

Frame feedback positively. Aim is for everyone to act as a critical friend.

\section{Limit the cues for change.}

Too many critical comments can be demotivating. Focusing on one key area is more helpful than trying to tackle everything. Match these to the stage of the writing (writer focused -still developing ideas or reader focused and need for polish and accuracy).

The writer is in charge.

While a writer needs to listen to the comments made about his or her writing, afterwards they decide whether to make the changes suggested, or make some and not others, or none at all.

\section{Writing Circles -Format}

\begin{tabular}{|l|l|}
\hline $\begin{array}{l}\text { Discussion } \\
\text { Objective setting }\end{array}$ & 5 \\
\hline $\begin{array}{l}\text { Everyone arrives with } 2 \text { pages of text they are ready to share and would like } \\
\text { feedback on. Share work }\end{array}$ & 5 \\
\hline $\begin{array}{l}\text { Read - Mark work } \mathbf{2} \text { stars and a wish } \\
\text { (2 things you like I you think are done well and } \\
\mathbf{1} \text { thing you would like to develop/improve) }\end{array}$ & 20 \\
\hline $\begin{array}{l}\text { In turn address one person's work at a time } \\
\text { The writer remains quiet at this time! } \\
\text { Return hard copy of drafts at the end. }\end{array}$ & 20 \\
\hline $\begin{array}{l}\text { Recap - what are you going to work on next? } \\
\text { time for next meeting }\end{array}$ & 10 \\
\hline
\end{tabular}

\section{For the Facilitator}

- Separate writing from writer

- State facts about the work itself

- Discuss technical details of writing

- Avoid 'you' statements

- Use concrete writing strategies

- Maintain a positive focus - 2 stars and a wish (Pasternak et al., 2009)

These ideas and activities are drawn from the work and practice of colleagues, including Aitcheson (2003), Chihota (2008), Pasternak et al. (2009), Caukill (2017), Huerta et al. (2017) and Roberts et al. (2019). 